that Society's Council, the Institute of Physics was founded forty-five years later. The original scheme envisaged a kind of federation of societies interested in physics, to provide, among other objects, rooms for meetings, a library, and a common secretariat. In fact, the Institute's offices were in the Society's present rooms in South Kensington during 1927-49, and the Institute provided the secretariat for the Physical Society and the Optical Society, which themselves amalgamated in 1931. Broadly speaking, before the War the scientific meetings and publications of the Institute were confined to applied physics, while those of the Society were concerned more with pure physics. As, however, the boundary between these two aspects became less definite there has been increasing overlap in the activities of the two bodies and in their membership. It is not, therefore, surprising that during the past twenty years proposals for the amalgamation of the two bodies have been made repeatedly, and from time to time detailed proposals examined, until eventually a satisfactory solution was worked out. The executive officers of the new body are: Secretary, Dr. H. R. Lang; Editor and Deputy Secretary, Dr. A. C. Stickland; Deputy Secretary, Mr. N. Clarke. The registered offices and headquarters are at 47 Belgrave Square, London, S.W.1, and for the present, offices will also be retained at 1 Lowther Gardens, South Kensington, London, S.W.7.

\section{University of Toronto Computation Centre}

The Board of Governors of the University of Toronto has approved the proposal to construet, install and operate a copy of Illiac $I I$ as the major computing facility in the Computation Centre at the University of Toronto. This project is financed in part by a grant of 600,000 dollars from the National Research Council of Canada and the Sir Frederick Banting Fund. Illiac II is the high-speed computing machine now being constructed at the Digital Computing Laboratory of the University of Illinois. In it, solid-state devices are used as the main electronic parts. It is designed to be a very reliable and easily serviced machine. Its logical design is elaborate, novel and very efficient in large calculations. The construction at Toronto will be under the supervision of Profs. R. W. McKay and C. C. Gotlieb, who have been associated with the work at Illinois for the past four years. The University of Toronto plans provide special accommodation for the Centre in the new Physies Building to be occupied, it is hoped, in 1962.

\section{Appointments in Industry and Commerce}

THE annual report for 1959 of the Committee for Appointments, published in a supplement to the Oxford University Gazette of March 14, records that of 8,792 vacancies, 5,545 called for men with scientific qualifications, an increase of 2 per cent on the previous year, compared with 11.6 per cent increase in the demand for arts men for industry and commerce. Discussing the effect on graduate employment of the bulge in school population and of the trend to stay on in sixth forms of grammar and public schools, the report stresses the need to convince industrial firms that universities really are creaming off the best of the sixth-form leavers even when university places cannot keep pace with the rise in numbers of sixth formers who are up to normal entrance standards and when sandwich courses are very attractive to parents. Meanwhile, it is apparent that there are far too many mediocre graduates on the market, and three-quarters of the engineering graduates entering the engineering industry make competent specialized technical men but are not up to leading teams in difficult times. The emphasis in recruitment must be on good engineers who can handle people, practical men who can get results from ongineering ideas, and the Committee suggests that if the universities cannot prove that such are their products, industry could lose much of its interest in graduates. It is also suggested that there may be a tendency in some firms to concentrate, up to 1965 , on school-leavers to the exclusion or partial exclusion of graduates. The school-leaver is refreshingly attractive, being eager to get going in a job, lively, enthusiastic, not choosy, and in contrast with graduates who have been generally cosseted in choosiness and superficial indifference and an attitude suspiciously near that of "the world owes me a living". Pointing out that if the effect of the bulge and trend ultimately is to compel graduates to try harder to secure an appropriate job, graduates will benefit, and commenting on "the dreary procession of would-be B.Sc.'s" seen each year by industrial recruiters, the report suggests that sixth formers may constitute formidable competition in that they will have had two or three years experience.

\section{Choosing a Career}

To help young people in their choice of a career, some twelve years ago the Central Youth Employment Executive of the Ministry of Labour and National Service began a series of publications designed to give information about various occupations and the opportunities they provide entitled "Choice of Careers". The series has been remarkably successful and, altogether, 163 editions, many of them revisions of earlier issues, have been published. Total sales of all editions have been well over a million. To mark the issue of the 100th booklet, which is called "The Scientist", the Central Youth Employment Executive has reprinted the first booklet, "Choosing your Career", which deals with the fundamental questions which young people need to pose before selecting a particular occupation in which they intend to pursue a career (Choice of Careers Series No. 1. Pp. 32. 1s. 6d. net). Another booklet, "Laboratory Technicians and Assistants", is even more profusely illustrated and contains much information about an assistant's job in the laboratory (Choice of Careers Series No. 94. Pp. 56. 2s. 6d. net). It is surprising, therefore, that "The Scientist" should be produced with such little imagination and launched at half the cost of "Laboratory Technicians and Assistants" (Choice of Careers Series No. 100. Pp. 48. 1s. 3d. net). The text seems designed to show that the scientist's highest ambition should be to become a 'backroom boy' while, if he turns to industry, he may find jobs in plant management provided he is prepared to give 'technical guidance' in running the plant and not wish to accept "direct responsibility for production management". Little reference is made to the scientific training which our future administrators will need. The tone of the booklet appears to indicate that Whitehall is still controlled by men who believe that men of science can perform useful supporting roles as technical experts, but that direction should rest with men trained in the liberal arts. Fortheoming booklets in the series are to be "Mathematics" and "Applied Science and Technology". The booklets are obtainable from H.M. Stationery Office. 